\title{
Türkiye'de Müzik Terapi Uygulamalarında Kullanılan Müzikler
}

\author{
DOI: 10.26466/opus.584795 \\ * \\ Begüm Yılmaz - Ümit Kubilay Can** \\ * Müzikolog ve Müzik Öğretmeni, Kocaeli Türkiye \\ E-Posta: begumnazylmz@gmail.com \\ ORCID: 0000-0002-9159-1082 \\ ** Dr. Öğr. Üyesi, Kocaeli Üniversitesi, Güzel Sanatlar Fakültesi, İzmit / Kocaeli/ Türkiye \\ E-Posta: kubican gitar@hotmail.com \\ ORCID: 0000-0001-9197-2240
}

\section{Öz}

Türkiye'de müzik terapi henüz yeni yeni gelişmekte olan bir bilim dahıdır. Müzik terapide müziğin kullanımı, ilk başlarda ilkel kabilelerdeki inanış çerçevesinde kötü ruh olarak nitelendirdikleri hastalıkların iyileştirilmesi için kullanılırken daha sonraları bir bilim alanı olarak klinik ortamlarda kullanılmaya başlanmıştır. Klinik araştırmalarında seçilen müziklerde neye dikkat edildiği ve nasıl kullanıldığına yönelik belirli bir yöntem olmadığı görülmekte olup terapistin yaptı̆̆ı uygulamaya göre müzik seçiminin yapıldığı bilinmektedir. Bu araştırmada müzik terapi alanında kullanılan müziklerin incelenmesi amaçlanmaktadır. Bu doğrultuda müzik terapi alanında gerçekleştirilen akademik çalışmalarda yer alan müzik uygulamalarının içeriklerinin ne olduğu ve nasıl uygulandığ̊ konusu ile müzik terapi alan uzmanlarının bu yöndeki görüşlerinin neler olduğu konular bu araştırmanın problemi olarak belirlenmiştir. Bu araştırmada karma araştırma yöntemlerinden açıklayıcı desen kullanılmıştır. Karma yönteme göre bu çalı̧̧mada amaç edilen soruların bir bölümünün çözümünde nicel veriler, diğer soruların çözümünde ise nitel veriler kullanılmıştır Araştırmanın nicel verilerin belirlenmesine yönelik Türkiye'de yayınlanmış Uygulamalı Müzik Terapi çalışmaları içeren tüm yayınlar araştırmanın evrenini oluştururken çalışmanin örneklem grubunu ise gerçekleştirilmiş tüm makale ve tezler olarak belirlenmiştir. Araştırmanın nicel verilerin toplanılmasında yayınlanan makale ve tezler, müzik terapi ile ilgili çeşitli anahtar kelimeler ile saptanmıştır. Araştırmanın nitel verilerine yönelik mevcut durumun betimlenmesinde, araştırmacı tarafindan uzman görüş formu hazırlanmış ve alanında uzman beş uzmana uygulanmıştır. Araştırmanın sonucunda elde edilen verilere bakıldı̆̆ında, Türkiye'de uygulanan Müzik Terapi Uygulamalarında makam müziklerinin tercih edildiği, en fazla 60 dakika boyunca terapinin gerçekleştiği belirlenmiştir. Uygulama sürecinde Pasif müzik terapinin yanında Aktif müzik terapi eklenerek otantik çalgilarla makam müzikleri icra edildiği belirlenmiştir. Bazı uygulamalarda müzik ameliyat önce ve sonrasında bir kez dinletilmiş, bazılarında belirli bir hafta sürmüştür. Uzman görüşlerinden elde edilen bulgulara göre, müzik seçiminin bazen danışana bazen de terapiste ait olduğu, terapi sürecinde kişinin kendi müzik geçmişinin değerlendirilmesi gerektiği, hastanın durumuna göre pasif veya aktif müzik terapinin tercih edildiği saptanmıştır.

Anahtar Kelimeler: Müzik Terapi Uygulamaları, Müzik Terapi, Müzik, Terapi 


\title{
The Music Used in Music Therapy Practice in Turkey
}

$*$

\begin{abstract}
Music therapy is a newly emerging science in Turkey. Music was first used in music therapy by primitive tribes to cure diseases, which they called evil spirits, according to their beliefs, and, later on, came to be used in clinical setting as a field of science. Clinical studies show that there is no specific method to choose music or determine how to use it, and it is known that the music is chosen by therapists depending on their application. This paper aims at analyzing the music used in music therapy. Accordingly, the problem of this paper has been designated as the contents of musical practices included in academic studies on music therapy and how these practices are implemented, and opinions of music therapy specialists on the matter. Descriptive pattern was used as the mixed research method of this paper. According to the mixed method, quantitative data was used to solve some of the questions and qualitative data was used in other questions traced in this paper. Population of the study consists of all publications that contain Applied Music therapy studies published in Turkey to identify quantitative data, and sample group of the paper consists of all articles and theses. The articles and theses used to collect the quantitative data of the paper were identified using keywords related to music therapy. An expert opinion form was prepared by the researcher and presented to five experts in the field to describe the current situation concerning the qualitative data of the paper. Data obtained in the study shows that mode music is preferred in the Music Therapy Practices in Turkey, and the maximum duration of a therapy sessions is 60 minutes. Active music therapy accompanies passive music therapy and mode music is played in authentic instruments. Music is used once before and once after surgery in some of the applications and throughout a certain week in others. According to the findings obtained from expert opinions, music is selected by the client or the therapist, and the client needs to evaluate their own musical history during the therapy and passive or active music therapy is chosen based on patient status.
\end{abstract}

Keywords: Music Therapy Applications, Music Therapy, Music, Therapy 


\section{Giriş}

Müzik toplumlar için sanat dallarının en eskisi olarak kabul edilir. "Müzik, aslı Yunanca olan bir kelime olan "Mousike" veya "Mousa" kelimesinden alınmıştır. Yunan mitolojisine göre Tanrı Zeus'un kızları sayılan dokuz peri kızına "Mousa" (Muse-melek) adı verilmiştir. Eski Yunanlılar bu peri kızlarının tüm dünyanın güzelliklerini ve ahengini düzenlemekle görevli olduklarına inanırlardı. O yüzden bugün hemen hemen her dilde kullanıla gelmiş olan müzik kelimesi bu peri kızlarından dolayı "Müz" kökünden geldiği kabul edilmektedir" (Sönmez 2008, s.3). Müzik bazı ilkel toplumlarda tanrı ile haberleşmenin yolu olarak görülüp kutsal sayılmış, bazı çalgılar tanrının sesi olarak adlandırılmıştır.

Bekiroğlu (2011) çalışmasında dünyada müzik ile tedaviden şu şekilde bahsetmektedir; Müzikle tedavinin dünyada ve Türkiye'de binlerce ylllık bir geçmişi vardır. Illkel insanlar, kötü ruh veya cin adı verilen varliklarm hastalıklara neden olduklarına inanirlardı. Bu kötü varlıklar sihirbaz veya şamanların öncülüğünde gerçekleştirilen tedavi törenleriyle kontrol altına alınmaya çalışllırdı. Müzik, dans, ritm ve şarkılar da bu tedavi törenlerinin vazgeçilmez öğeleriydi. Antik döneme kadar hastalıkları tedavi etmek ya da kötü ruhları bedenden çıkarmak için kullanılan hızh, yavaş, sert ya da yumuşak melodiler ile ikna ve etkileyici sözlerden oluşan şarkılar müzikle tedavinin temelini oluşturmuştur. İlkçağ düşünürleri, müziğin temelini içinde yaşadı̆̆ımız evrenin doğal ritmik düzenine ve uyumuna bağlamışlardır. Ay, güneş, gezegenler, gece-gündüz, mevsimler her biri belli bir ritim içinde devinen, belli bir uyum sergileyen nesne ve olaylardır. Ayrıca, insan bedeninin yapısı, işleyişi de müzikteki ritim ve uyum öğglerini taşımaktadır (31).

Çeşitli müzik terapi dernekleri çalışmalarını beraber yürüterek bireylerin ruh ve bedensel sağlıklarına kavuşmalarında önemli çalışmalar yaparak tıp dünyası içerisinde etkin bir rol oynamaktadır. Dünyada müzik terapi alanında kurulmuş en önemli derneklerin başında Amerikan Müzik Terapi Birliği gelmektedir. Bu kuruluş 1997 yılında müzik tedaviyi "İhtiyaç duyan bireylerin fiziksel, psikolojik, sosyal ve zihinsel ihtiyaçlarım karşılamada müziği ve müzik aktivitelerini kullanan bir uzmanlık dalı" olarak tan1mıştır (Horuz, 2014, s.26).

'Eski zamanlarda şairlik, müzisyenlik ve doktorluk çoğunlukla bir kişinin şahsinda toplanirdi. Terpandr Talet, Tirte, ElliEnne, hem doktor hem de müzisyen 
idiler. Xenokrates, Hipocrate, Asclepiade, Colinos Areteus, Cacleius, Theofraste, tıp ilminin diger yaşıtlarını faydasız, sonuçsuz kaldığı hastalarda müzik kullanmıştır' (Ak, 1997, s.14). Tarihte birçok toplum müziği hem sanat hem de tıp biliminin içine almış ve araştırmalar yapmıştır. Türklerde Müzik terapi tarihi çok eskiye dayanmakla birlikte açmış oldukları hastanelerde müziği terapinin içerisinde kullanarak hastaları şifalandırmayı sağladıkları bilinmektedir.

"1693 yılında öldüğü bilinen, Osmanlının şair hekimlerinden Şuuri Hasan Efendi," Tadil-i Emzice adl eserinde, makamlarm hangi durumlarda, hangi vakitlerde etkili olduğunu, hangi gezegenle hangi makamın nasıl etkileştĭgini yazmıştır. Şuuri, araştırmaların daha da yoğunlaştırarak, hangi makamın hangi meclis insanına, hangi makamın hangi milletin insanlarna etki ettiğini bile bildirmiştir. Şuuri'ye göre ;

- Bilim adamları üzerinde Rast makamı ve benzerleri etkilidir.

- Yöneticiler üzerinde ısfahan ve benzerleri etkilidir.

- Dervişler için hicaz ve benzerleri etkilidir.

- Sufiler için ise rehavi ve benzerleri etkilidir.

Hasan Şuuri'nin "Tadil-i Emzice'sinde " ve Haşim Bey mecmuası'nda neva, buselik, mahur, nihavend, buselikaşiran ve uşsak makamlarmm insana kuvvet verdiğinden, bu makamlarm Afrika ve Avrupa halklarma da etkisi olduğundan bahsedilir. Hasan Şuuri, kitabında müzik bilmeyen hekimin tanı ve tedavide başarılı olmayacağım iddia etmiştir" (Uygun, 1999, s.237).

Büyük Türk bilgini Farabi günümüz müzikle tedavisine de büyük katkıları olan "musiki - ul - kebir" adlı eserinde, makamların insan ruhuna olan etkilerini şöyle sınıflandırmıştır (Öztürk, Erseven ve Atik, 2017).

- Rast Makamı : İnsana neşe huzur verir.

- Rehavi Makamı : İnsana sonsuzluk fikri verir.

- Küçük Makamı : İnsana hüzün verir.

- Büzürk Makamı : İnsana korku verir.

- İsfehan Makamı : İnsana hareket kabiliyeti ve güven hissi verir.

- Neva Makamı : İnsana lezzet ve ferahlık verir.

- Uşşak Makamı : İnsana gülme hissi verir.

- Zirgüle Makamı : İnsana uyku verir.

- Saba Makamı : İnsana cesaret kuvvet verir.

- Buselik Makamı : İnsana kuvvet verir.

- Hüseyni Makamı : İnsana sessizlik ve rahatlık verir. 
- Hicaz Makamı : İnsana alçak gönüllülük verir.

Müzik terapi Osmanlı döneminden bu zamana gelmiş köklü bir yapıdır. Günümüzde kesintili bilgilerle ilerlemekte olan Müzik terapi hakkında araştırmalar yapılıyor, aynı zamanda birçok kuruluşlarda uzmanlar tarafından eğitimler veriliyor. Ülkemizdeki 1976 yılında Türk müziğinin doğuşunu, gelişimini, tedavi değerini, repertuar ve eser zenginliğini araştırma ve tanıtma için Oruç Güvenç tarafından TÜMATA (Türk Musikisini Araştırma ve Tanıtma Grubu), 2004 yılında müzik terapisi alanındaki büyük boşluğu doldurmak adına Adnan Çoban ve arkadaşları tarafından TÜTEM (Türk Tedavi Musikisi Uygulama ve Araştırma Grubu), 2013 y1lında ise müzik terapisinde çağdaş tıbbın, psikoloji ve psikiyatride kullanılan çeşitli yöntemlerini uygulamalarla zenginleştirip eğitim-öğretime katkısı olan araştırmalar yapmak amacıyla Üsküdar Üniversitesi'ne bağlı olarak MÜTEM (Müzik Terapi Uygulama ve Araştırma Merkezi) kurulmuştur (Uçaner ve Öztürk, 2009).

Müzik terapinin aktif ve pasif olarak uygulanan iki kolu vardır.

- Aktif müzik terapi de hastaların müzik aletlerini, vücutlarını, seslerini kullanarak ve müzik deneyimleriyle kendilerini, sıkıntılarını anlatmaya teşvik edilerek yapılan tedavi yöntemidir (Stanczyk, 2011). Aktif müzik terapide bireyin veya grubun müzik yapması ya da müzik yaratmasına yardımcı olarak müziğin içinde olması sağlanır. Ayrıca aktif müzik terapinin bir başka yolu da müzik ritmine uyularak yapılan danstır (Gençel, 2006).

- Pasif müzik terapi ise, geleneksel Türk müzik terapide en çok kullanılan yöntemdir. Pasif müzik terapi, danışan daha çok dinleyici pozisyonunda ve terapistin yönlendirmesiyle terapist tarafından canlı veya kayıttan müzik dinletilerek yapılır. Dinletilen müzik kişiye özel hedefler doğrultusunda seçilmesi, danışanın tedavisini doğru amaçlara ulaştırır. Bu teknikte hasta, bir seans boyunca geniş ve rahatlatıcı müzikler dinletilir. Terapiye katılan kişilerden, dinletilen müziğe tamamen konsantre olmaları ve kendilerini müziğin akışına bırakmaları istenir (Wigram ve Groke, 2007).

Müzik terapi de birçok temel yöntem vardır ve danışan (hasta) bu yöntemlerin en az birinden geçer. Terapiyi anlamak ve bunu uygulayabilmek için bütün işleyişlerin farkında olmak ve onları uygulamış olmak gerekir. 
Müziği deneyimlerken dinler, doğaçlama yapar, besteler, yeniden yaratırız bu aşamalar müzik terapinin de temel yöntemleri arasına girmiştir. Her yöntemin belirli kuralları vardır. Doğaçlama yöntemiyle götürülen bir seans için danışanın öncelikli enstrüman seçmesi, onu tanıması, belirli çerçevede (terapistin koymuş olduğu kurallar) doğaçlar ve ardından doğaçlamalar tartışılır. Bunun gibi uygulanması gereken bir çizgi vardır.

Doğaçlama müzik deneyiminde danışan, müzik aleti çalarak ya da şarkı söyleyerek sürece katılır, kendi isteği doğrultusunda herhangi enstrümanı kullanabilir. Terapist bu süreçte yönlendirme yaparak danışanın terapide resmetmesi gereken fikri sunar. İletişimde sözsüz bir kanal oluşturma, zor duyguları tanımlama, ifade özgürlüğü, duygu uyarma ve geliştirme, algısal ve bilişsel beceri geliştirme doğaçlama müzik terapinin amaçlarındandır. Doğaçlama müzik terapide, referanssız (danışan, içinden gelerek müzik yapar), referanslı (danışan, herhangi bir olay,anı, duygu,fikir referanslı müzik yapar), şarkı doğaçlama (danışan, şarkı sözlerini içinden geldiği gibi söyler), Referanssız vokal doğaçlama (danışan, kelimeler olmadan doğaçlama yapar), Beden doğaçlama (bedeni kullanarak melodi oluşturma), Karma araçlı doğaçlama (sesini kullanarak yapma), Yönetilen doğaçlama (danışanın diğerleriyle doğaçlama yapması) olarak çeşitlendirilir (Bruscia, 2016). Hazırlıksız müzik yaratılması fiziksel hareketleri düzenlemekte, yeni fikirleri bulmakta, estetik deneyime sahip olmakta, başkalarıyla iletişime girmekte ve duyguları geliştirmekte hastalara yardımcı olur (Wheeler, 2015, s.117). Bu model müziğin bilinçaltını ortaya çıkarmasına yol açar. Müzikal kurallar olmaksızın doğaçlama olarak yapılan müziğin kişinin karakter ve benliğinin ifadesi olacağı kabul edilmiştir. Organize olmamış sesler kullanılarak oluşturulan müzikal tınılar terapiste ve danışana özgürlük alanı açar (Wigram ve Groke, 2007, s.131).

Reseptif metot, müziği dinlemeye dayanır. Reseptif Müzik Terapi yönteminde kullanılan müzik, canlı veya kayıtlı doğaçlama, performans dışında müzik literatüründeki herhangi bir bestede olabilir. Belirli bir tepkiyi uyandırmak, kişiyi sakinleştirmek, işitme/ motor becerilerini geliştirmek, yoğun ve ruhani deneyimleri uyandırmak reseptif müzik terapi yönteminin amaçlarındandır. Bedensel dinleme (kenetlenme, rezonans, vibroakustik müzik, müzikli biofeedback), Ağrı yönetiminde müzik, Müzikle gevşeme, Meditatif dinleme, Biliç̧ışı dinleme, Uyarıcı dinleme, Ritme 
uyumlu dinleme, Algisal dinleme, Hareketli dinleme, Olumsal dinleme, Aracı dinleme, Müzik değerlendirme aktiviteleri, Şarkıyla Hatırlatma, Şarkıyla geri getirme, Şarkıyla tetiklenen anımsama, Şarkı üzerinden iletişim, Şarkı irdeleme, Yansıtmalı, İmgelemli dinleme, Kendini dinleme olarak çeşitlendirilir.

Yeniden yaratma müzik terapi yönteminde danışan daha önceden bildiği besteyi söyler, çalar, icra eder. Müzik aktiviteleri ve oyunları bu metotun kullanımı arasındadır. Yeniden yaratma bir müzikal ürünün herhangi bir parçasını yorumlamaya yeniden geliştirmeye dinleyici olmadan üretmeyi içinde barındıran geniş bir metotdur. Hafıza becerilerini artırmak, kendini duyma ve izleme becerisi geliştirmek, fikir ve duyguları algılamayı ve yorumlamayı geliştirmek, diğer insanlarla empati kurmayı desteklemek bu metodun amaçlarındandır. Enstrümantal Yeniden Yaratım (Bir enstrüman çalma), Vokalle yeniden yaratma (şarkı söyleme), icra, müzikal sahneleme, müzikal oyunlar faaliyetler, yönetme gibi çeşitleri vardır (Bruscia, 2016).

Besteleme metodunda, terapist danışana şarkı besteleme, söz yazma, müzik videoları, ses kayıtları hazırlama gibi ürün yaratımında yardım eder. Kişinin kendi düşüncesini ifade edebilmesi, karar verme kabiliyetini geliştirmesi, beste yaratımının sağlanması, sözlerle bağ kurma gibi faatliyetler amaçlanmıştır. Şarkı dönüştürme, şarkı yazarlığı, enstrümantal beste, notasyon faaliyetleri, müzik kolajı çeşitleri olan besteleme yönteminde danışanın müzikal yeteneklerine göre katılım sağlanır (Bruscia, 2016). Bu yöntemin varyasyonları enstrümantal besteleme, müzik düzenleme ve şarkı yazımı kullanılır. Çünkü popüler şarkı kültürü her yerde ve her yaşta bulunur; radyoda, televizyonda ve internette hastalar erişilebilir. Bireysel ve grup halinde, hastalar sıfırdan bir şarkı yazabilir veya var olan bir şarkıya yeniden söz ve / veya buna göre müzikal elementleri değiştirerek hazır bir şarkı yapısını, dönüştürebilir. Terapistin rolü besteleme sürecinde teknik yardım sağlamaktır. Terapist bir grup tanıyarak ve onların ortak amaca ve yaratıcı süreç içinde ortaya çıkabilecek farklılıkları uzlaştırarak üyelerine yardım, kolaylaştırıcı ve arabulucu olarak hizmet vermektedir (Wheeler, 2015, s.118). Aynı zamanda terapist müzik terapide danışana uygulanacak doğru yöntemi seçmek zorundadır. ABD'de en az 15 farklı model, 100 farklı tekniği olan müzik terapi yöntemleri fazla karmaşıklığından dolayı, 9. Dünya Müzikterapi Kongresi'nde sınırlandırıldı. 
Türkiye'de müzik terapi uygulamalarına geldiğimizde müzik terapi konusunda herhangi bir eğitim veren akademik bir yapı yoktur. TÜTEM, TÜMATA (Türk Musikisini Araştırma ve Tanıtma Grubu), MÜZTED gibi kuruluşlar günümüzde müzik terapi üzerine araştırmalar yaparak aynı zamanda müzik terapiyi tanıtmak amaçlı seminer ve atölye çalışmaları düzenlemektedirler. Türkiye'de üniversitelere bağlı tıp fakültelerinde Türk Müziği ile tedavi çalışmaları başlamış ve bu çalışmalar büyük önem kazanmıştır (Uçaner ve Öztürk, 2009). Türkiye' de müzik terapi alanında yapılan çalışmalardan bazıları şu şekildedir:

Ersanlı (2007)'nın çalışmasına göre; 2005-2006 yılları arasında indüksiyon uygulanan primipar gebelere travayda verilen eğitim ile dinletilen müziğin doğum sürecine etkisi adlı çalışmanın sonuçları şöyledir:

Araştırmaya 40 deney, 40 kontrol grubu toplam 80 gebe katılmıştır. Deney grubundaki gebelere eğitim verilmiş, doğum ağrılarına iyi geldiği bilinen Rehavi makamındaki müzik birer saat arayla, her saatte 20 dakika olmak koşulu ile en az $6 \mathrm{kez}$ dinletilmiştir. Kontrol grubundaki gebelere eğitim verilmemiş, müzik dinletilmemiştir. Müziğin gebelerin doğum ağrılarının endişe ve duyarlılığını azaltarak ağrının yarattığı sıkıntıların artmasında gecikmelere neden olmuştur. Araştırma sonucunda indüksiyon uygulanan primipar gebelere travayda verilen eğitim ile dinletilen müziğin doğum sürecine olumlu etkileri olduğu saptanmıştır.

Yıldırım ve Gürkan (2007)'ın çalışmasına göre, 2007 yılında Ege Üniversitesi Hastanesi Onkoloji bölümünde kanser hastaları üzerinde müziğin kemoterapi yan etkilerine ve kaygı düzeylerine etkisi araştırılmıştır. Araştırmaya 30 deney ve 30 kontrol grubu olmak üzere toplam 60 hasta katılmıştır. Bu hastalar müziğin dinlendirdiğini, rahatlattığını, huzur verdiğini, hoşlarına gittiğini, mutlu ettiğini, zevk verdiğini, kendilerini özel ve önemli hissettirdiğini, dikkatlerini hastalıktan, tedaviden ve ortamdan uzaklaştırdığını, hayal kurmalarına yardım ettiğini, ortamı daha katlanır duruma getirdiğini belirtmiştir.

‘Gazi Üniversitesi ve TUMATA (Türk Müziği Araştırma ve Tanıtma Grubu) işbirliği ile yapılan her iki çalışmada (ă̆rılı hastalar ve otistik bozukluklu çocuk ve ergenler) da aktif ve pasif müzik terapi uygulanmaktadır. Terapinin ilk bölümü olan aktif müzikoterapide "Baksı Dansı" adı verilen hareketlerle Türk Müziği enstrümanlarn ile yapılan müzik eşlik etmektedir. İkinci bölümde ise hastalar genellikle oturarak veya uzanarak rahat bir pozisyonda doğaçlama olarak 
seslendirilen Türk Müziği'ni dinlemektedirler. İcra edilen müzikte su sesi eşliğinde ney, rebap, çeng, ud, dombra, rebab vb. Türk Müziği Çalgıları kullanılmaktadır' (Uçaner ve Tufan, 2008, s.38).

Arslan ve Özer (2007) yaptığı çalışmada öntest sontest kontrol gruplu, anestezi YBÜ'de yatan hastalarla yaptıkları müzik terapinin hastaların nabız değeri üzerine etkisini araştıran çalışmalarının sonucunda deney grubu nabız ortalamalarında önemli bir azalma bulmuşlardır

\section{Problem}

Türkiye' de müzik terapi henüz yeni yeni gelişmekte olan bir bilim dalıdır. Müzik terapide müziğin kullanımı, ilk başlarda ilkel kabilelerdeki inanış çerçevesinde kötü ruh olarak nitelendirdikleri hastalıkların iyileştirilmesi için kullanılırken daha sonraları bir bilim alanı olarak klinik ortamlarda kullanılmaya başlanmıştır. Müzik terapi, ilk uygulamalarında belirli bir hastalığın üzerinde hastalara müzik dinletilirken daha sonraları psikolojinin alt alanları arasına girmiştir. Müzik terapinin uygulamasının ana karakterlerinden biri dinletilen müziktir. Klinik araştırmalarında seçilen müziklerde neye dikkat edildiği ve nasıl kullanıldığına yönelik belirli bir yöntem olmadığ 1 görülmekte olup terapistin yaptı̆̆ 1 uygulamaya göre müzik tercihi yaptığı bilinmektedir. Bu araştırmada Türkiye'de müzik terapi alanında kullanılan müziklerin incelenmesi amaçlanmaktadır. Bu doğrultuda müzik terapi alanında gerçekleştirilen akademik çalışmalarda yer alan müzik uygulamalarının içeriklerinin ne olduğu ve nasıl uygulandığı konusu ile müzik terapi alan uzmanlarının bu yöndeki görüşlerinin neler olduğu konuları bu araştırmanın problemi olarak belirlenmiştir.

\section{Amaç}

Türkiye'de Müzik Terapi Uygulamalarında Kullanılan Müzikler ve bu doğrultudaki uzman görüşlerinin incelenmesi bu araştırmanın amacıdır. Araştırmanın amacı doğrultusunda aşağıdaki sorulara cevap aranacaktır.

1. Türkiye'de gerçekleşen müzik terapi çalışmalarında yer alan uygulamaların içeriği ve kullanılan müziklerin özellikleri nelerdir? 
Müziğin terapide etkisinin ölçülmek istenildiği uygulamalı araştırmalar tasarlarken;

2. Uygulamalı Müzik Terapi ortamlarında kullanılmak istenilen müziklerin seçiminde dikkat alınması gereken hususlar nelerdir?

3. Müzikle Terapide aktif veya pasif uygulamalardan hangisi tercihi edilmelidir?

4. Müzikle Terapide müziğin kullanımını kapsayan uygulama aşaması genel olarak,

a) Nasıl bir sıra ile gerçekleşebilir?

b) Bu süreçte nelere dikkat edilmelidir?

Müzik terapi uygulamalarında kullanılan müziklerin özellikleri, terapideki yeri gibi sorular alanda tartışma konusu olmuştur. Bu sebeple gerçekleştirilecek araştırma sonuçlarının yapılan araştırmaların kullanılan müziğin içeriğinin belirlenmesi ve konu ile ilgili uzman görüşü alınması ile güncel durumun ne olduğu konusuna ışık tutacağı düşünülmektedir. Ayrıca bundan sonra yapılacak çalışmalarda araştırma sonuçlarının araştırmacilara ve terapistlere yol göstereceği düşünülmektedir. Bu araştırmada müziğin terapi sürecine nasıl dahil olduğunu görmekle birlikte uzmanlardan müziğin kullanımı hakkındaki görüşleri alınmıştır. Araştırmanın öğrenciler, terapistler, müzik terapistleri, doktorlar ve araştırmacılar açısında önemli olduğu düşünülmektedir.

Bu çalışmada Uygulamalı Müzik Terapi çalışmalarının kullanılan müziklerin belirlenmesinde 2019 yılının nisan ayına kadar Türkiye'de yayınlanmış makale ve tezler ile sınırlandırılmıştır.

\section{Yöntem}

\section{Araştırma Modeli}

Araştırmada elde edilen verilerin toplanması, analizi ve yorumlanmasında karma yöntem kullanılmıştır. Karma yöntem, nicel ve nitel yöntemlerin birlikte kullanılarak araştırma problemi ve sorularının daha iyi anlaşılacağ1 ve inceleneceği üzerinedir (Creswell, 2013).

Bu araştırmada karma araştırma yöntemin kararının verilmesinde Greene, Caracelli ve Graham (1989) tarafından oluşturulan beş temel gerekçe 
incelenmiştir. Bunlar çeşitleme, tamamlama, gelişim, başlatma ve genişletmedir. Çeşitlemede aynı olayın değerlendirilmesinde farklı yöntemler kullanılarak bulguların tutarlılığı sağlanır.

Çalışmada karma araştırma yöntemlerinden açıklayıcı desen kullanılmıştır. Açıklayıcı desende çalışmada araştırma sorularına yönelik olarak önce nicel veriler toplanır ve ardından elde edilen verileri tamamlamak için nitel veriler ile ilişkilendirilir (Creswell, 2017).

Araştırma yaklaşımı doğrultusunda bu çalışmanın amaç edilen soruların bir bölümünün çözümünde nicel veriler, diğer soruların çözümünde ise nitel veriler kullanılmıştır. Araştırmanın nicel verilerin toplanılmasında yayınlanan makale ve tezler, müzik terapi ile ilgili çeşitli anahtar kelimeler ile saptanmıştır. Araştırmanın nitel verilerine yönelik Mevcut durumun betimlenmesinde, araştırmacı tarafından açık uçlu bir uygulama anketi hazırlanmıştır. Bu çalışmada, anket tekniği yoluyla güncel veriler toplanılmış ve uzmanlardan alınan cevaplar bulgular kısmında aynen sunulmuş olup çalışma kapsamındaki genelleme ve değerlendirmelere sonuç kısmında yer verilmiştir.

\section{Evren ve Örneklem}

Araştırmanın nicel verilerin belirlenmesine yönelik Türkiye'de yayınlanmış Uygulamalı Müzik Terapi çalışmaları içeren tüm yayınlar araştırmanın evrenini oluştururken çalışmanın örneklem grubunu ise gerçekleştirilmiş tüm makale ve tezler olarak belirlenmiştir. Araştırmanın nitel verilerin elde edilmesinde müzik terapi alanında seçilen beş uzman ile belirlenmiştir. Türkiye de müzik terapi alanında uzman sayısının az olduğu düşünüldüğünde, veri toplamak üzere seçilen beş uzman araştırmanın örneklem grubunu oluşturmaktadır.

\section{Veri Toplama Araçlan}

Araştırmanın nitel verilerin toplanılmasında farklı anahtar kelime kullanarak tezler ve makaleler taranarak elde edilmiştir. 


\section{Uzman Görüş Formu}

Yapılandırılmış görüş formunda, amaca yönelik sorular hazırlanır (Karataş ve Yavuzer, 2015). Açık uçlu sorular, katılımcılardan serbestçe cevap vermelerinin istenmesi durumunda tercih edilir. Yapılandırılmamış sorular olarak da bilinen açık uçlu sorularda cevaplayıcı, soruya serbestçe cevap verir. Bu tür soruların avantajı, araştırmacının beklemediği veya planlamadığı cevapları da alabilmesi ve böylece konu hakkında daha geniş ve ayrıntılı bilgiye sahip olunabilmesidir (Büyüköztürk, 2005). Araştırmada veri toplama aracı olarak bir uygulama anketi olan yapılandırılmış uzman görüş formu kullanılmıştır. Uzman görüş formu araştırmacılar tarafından oluşturulmuş açık uçlu dört sorudan oluşmaktadır.

\section{Verilerin Çözümlenmesi}

Araştırmada taranarak elde edilen uygulamalı müzik terapi çalışmaları tek tek incelenmiştir. Çalışmaların içeriklerine göre elde edilen veriler, "Kullanılan Müziklerin Özellikleri" ve "Terapi Uygulamalarının İçeriği" olarak alt boyutları ile tez ve makale olarak iki ayrı tabloda sunulmuştur. Uzman görüş formu, alanı derinlemesine inceleyen spesifik uzmanlık sorularından oluşmaktadır. Bu nedenle uzmanlardan elde edilen veriler olduğu gibi yazılmıştır. Araştırmanın sonuç kısmında elde edilen bu veriler değerlendirilerek tartışılmıştır. 


\section{Bulgular}

Türkiye'de gerçekleşen müzik terapi çalışmalarında yer alan uygulamalarnn içeriği ve kullanılan müziklerin özellikleri nelerdir?

Tablo 1. Uygulamalı müzik terapi konulu Lisans üstü tezlerinin, içeriklerinde yer alan müziklerin özellikleri ve uygulandı̆̆ı terapi yöntemlerine göre dağılımları

\begin{tabular}{|c|c|c|c|c|c|c|c|c|}
\hline \multirow{3}{*}{$\begin{array}{l}\text { Tez } \\
\text { Kodu }\end{array}$} & \multicolumn{4}{|c|}{ Kullanılan Müziklerin Özellikleri } & \multicolumn{4}{|c|}{ Terapi Uygulamalarının İçeriği } \\
\hline & \multirow[t]{2}{*}{ Tür } & \multicolumn{2}{|c|}{ Dinletim şekli } & \multirow[t]{2}{*}{ Yer } & \multirow[t]{2}{*}{ Süreç } & \multirow{2}{*}{$\begin{array}{l}\text { Haftalık } \\
\text { Terapi } \\
\text { Süresi }\end{array}$} & \multirow{2}{*}{$\begin{array}{l}\text { Denek } \\
\text { Sayısı }\end{array}$} & \multirow{2}{*}{$\begin{array}{l}\text { Eser } \\
\text { Sayısı }\end{array}$} \\
\hline & & Canlı & $\begin{array}{l}\text { Ka- } \\
\text { yit }\end{array}$ & & & & & \\
\hline T1 & $\begin{array}{l}\text { Pop+ } \\
\text { Sanat } \\
\text { Müziği }\end{array}$ & $\begin{array}{l}\text { Tef,Def, } \\
\text { Uklele, } \\
\text { Gitar }\end{array}$ & $\mathrm{Cd}$ & Huzurevi & $\begin{array}{l}16 \\
\text { Hafta }\end{array}$ & $60 \mathrm{dk}$. & 30 & 5 \\
\hline T2 & $\begin{array}{l}\text { Klasik } \\
\text { +Türk Sanat } \\
\text { Müziği }\end{array}$ & & MP3 & Klinik & 15 gün & $60 \mathrm{dk}$. & 96 & - \\
\hline T3 & $\begin{array}{l}\text { Türk } \\
\text { Sanat } \\
\text { Müziği }\end{array}$ & Ney & $\mathrm{Cd}$ & - & 3 Hafta & $70 \mathrm{dk}$. & 58 & 4 \\
\hline T4 & - & Kaval & & $\begin{array}{l}\text { Hastane } \\
\text { Ünitesi }\end{array}$ & $\begin{array}{l}\text { Bir } \\
\text { Kez }\end{array}$ & $30 \mathrm{dk}$. & 34 & 11 \\
\hline T5 & - & - & $\mathrm{Cd}$ & $\begin{array}{l}\text { Özel Tedavi } \\
\text { Odası }\end{array}$ & - & $40 \mathrm{dk}$. & 60 & - \\
\hline T6 & $\begin{array}{l}\text { Klasik Türk } \\
\text { Müziği }\end{array}$ & - & $\mathrm{Cd}$ & $\begin{array}{l}\text { Rehabilitas- } \\
\text { yon Merkezi }\end{array}$ & $\begin{array}{l}28 \\
\text { Gün }\end{array}$ & $25 \mathrm{dk}$. & 60 & - \\
\hline T7 & $\begin{array}{l}\text { Gevşeme } \\
\text { Müziği }\end{array}$ & - & $\mathrm{Cd}$ & $\begin{array}{l}\text { Kemoterapi } \\
\text { Ünitesi }\end{array}$ & $\begin{array}{l}1 \\
\text { hafta }\end{array}$ & $30 \mathrm{dk}$. & 70 & - \\
\hline T8 & $\begin{array}{l}\text { Hüseyni } \\
\text { Makamı }\end{array}$ & - & $\mathrm{Cd}$ & $\begin{array}{l}\text { Kardiyo- } \\
\text { loji Servisi }\end{array}$ & - & $10 \mathrm{dk}$. & 200 & - \\
\hline T9 & $\begin{array}{l}\text { Klasik Türk } \\
\text { Müziği- } \\
\text { Türk Halk } \\
\text { Müziği }\end{array}$ & - & $\mathrm{Cd}$ & $\begin{array}{l}\text { Yoğun Ba- } \\
\text { kim Üni- } \\
\text { tesi }\end{array}$ & $\begin{array}{l}\text { Ameli- } \\
\text { yat son- } \\
\text { rasinda } \\
\text { bir defa. }\end{array}$ & $30-60 \mathrm{dk}$ & 68 & - \\
\hline T10 & $\begin{array}{l}\text { Hüseyni- } \\
\text { Nihavent } \\
\text { Makamları, } \\
\text { Ney Enstrü- } \\
\text { manı }\end{array}$ & - & $\begin{array}{l}\text { crea- } \\
\text { tone } \\
\text { mu- } \\
\text { sic } \\
\text { pil- } \\
\text { low- } \\
\text { mp3 }\end{array}$ & $\begin{array}{l}\text { Ordu } \\
\text { Medical } \\
\text { Park } \\
\text { Hastanesi }\end{array}$ & $\begin{array}{l}\text { Kontrol G } \\
\text { (4 ay) } \\
\text { Deney G } \\
\text { (3 Ay) }\end{array}$ & $40 \mathrm{dk}$. & 66 & - \\
\hline T11 & $\begin{array}{l}\text { J. S. Bach'ın } \\
\text { Eserleri }\end{array}$ & - & Mp3 & $\begin{array}{l}\text { Ege Üni- } \\
\text { versitesi }\end{array}$ & 2 ay & $60 \mathrm{dk}$. & 60 & - \\
\hline
\end{tabular}




\begin{tabular}{|c|c|c|c|c|c|c|c|c|}
\hline T12 & - & - & Mp3 & Klinik & $\begin{array}{l}\text { Ameliyat } \\
\text { önce-son- } \\
\text { rasında } \\
\text { bir defa } \\
\end{array}$ & $15 \mathrm{dk}$. & 60 & - \\
\hline T13 & $\begin{array}{l}\text { Bach'ın } \\
\text { keman ve } \\
\text { violin } \\
\text { konçertosu }\end{array}$ & - & $\mathrm{Cd}$ & $\begin{array}{l}\text { Araştırma } \\
\text { İnönü } \\
\text { Üniversitesi }\end{array}$ & - & $30 \mathrm{dk}$. & 202 & - \\
\hline T14 & $\begin{array}{l}\text { Rast } \\
\text { Makamı } \\
\text { Müzik Cdsi }\end{array}$ & - & $\mathrm{Cd}$ & $\begin{array}{l}\text { Edirne } \\
\text { Huzurevi }\end{array}$ & $\begin{array}{l}10 \text { gün } \\
20 \mathrm{kez}\end{array}$ & $30 \mathrm{dk}$. & 38 & - \\
\hline T15 & $\begin{array}{l}\text { Rast ve } \\
\text { Mahur } \\
\text { Makamları }\end{array}$ & - & Mp3 & $\begin{array}{l}\text { Gastroen- } \\
\text { teroloji } \\
\text { ünitesi }\end{array}$ & & $20 \mathrm{dk}$. & 60 & - \\
\hline T16 & $\begin{array}{l}\text { Rast } \\
\text { ve Uşak }\end{array}$ & - & Mp3 & $\begin{array}{l}\text { Hemodi- } \\
\text { yaliz } \\
\text { Ünitesi }\end{array}$ & $\begin{array}{l}1 \text { hafta } \\
3 \mathrm{kez}\end{array}$ & $30 \mathrm{dk}$. & 100 & - \\
\hline T17 & $\begin{array}{l}\text { Türk } \\
\text { Musikisi }\end{array}$ & - & $\mathrm{Cd}$ & $\begin{array}{l}\text { Atatürk } \\
\text { Üniversi- } \\
\text { tesi }\end{array}$ & 7 gün & $49 \mathrm{dk}$. & 60 & - \\
\hline T18 & $\begin{array}{l}\text { Ney } \\
\text { Müziği- } \\
\text { Klasik Türk } \\
\text { Müziği- } \\
\text { Klasik Batı } \\
\text { Müziği } \\
\end{array}$ & - & $\mathrm{Cd}$ & $\begin{array}{l}\text { Lise - Üni- } \\
\text { versite }\end{array}$ & 8 Hafta & $30-40 \mathrm{dk}$ & 131 & 43 \\
\hline T19 & - & - & - & $\begin{array}{l}\text { Hacettepe } \\
\text { Üniversitesi }\end{array}$ & $\begin{array}{l}6 \\
\text { Hafta } \\
\end{array}$ & $60 \mathrm{dk}$. & 20 & - \\
\hline T20 & - & - & - & $\begin{array}{l}\text { NP İstanbul } \\
\text { Nöropsikiyatr } \\
\text { Hastanesi }\end{array}$ & tri & - & 101 & - \\
\hline T21 & - & $\begin{array}{l}\text { Şaman } \\
\text { Davulu }\end{array}$ & $\mathrm{Cd}$ & $\begin{array}{l}\text { Şizofreni } \\
\text { Dostları } \\
\text { Derneği }\end{array}$ & $1 \mathrm{Hafta}$ & $60 \mathrm{dk}$. & 27 & - \\
\hline T22 & $\begin{array}{l}\text { Buselik } \\
\text { Makamı }\end{array}$ & Canlı & - & $\begin{array}{l}\text { Fransiz } \\
\text { Lape } \\
\text { hastanesi }\end{array}$ & 17 gün & $30 \mathrm{dk}$. & 22 & - \\
\hline
\end{tabular}

Tablo 1 de elde edilen verilere göre, tez çalışmalarında yürütülen müzik terapi uygulamalarında genellikle pasif müzik terapi tercih edildiği görülmektedir. Gerçekleştirilen müzik terapide makam müziği cdleri kullanılmıştır. Terapiler en az 10, en fazla 70 dakika sürmüştür. Uygulama sürecinde Pasif müzik terapinin yanında Aktif müzik terapi eklenerek bazı otantik çalgılarla icra gerçekleşmiştir. Bazı uygulamalarda müzik ameliyat önce ve sonrasında bir kez dinletilmiş, bazılarında belirli bir hafta sürmüştür. Türkiye'de yapılan bu uygulamalı çalışmalarda Klasik 
müziğin, Türk halk müziği makamlarına göre daha az kullanıldığ1 saptanmıştır.

- T1: Demans - Alzheimer Hastalarında Farklı Müzik Terapi Uygulamalarının Zihinsel, Psikolojik, Anksiyete Ve Ajitasyon Etkileri Üzerine Karşılaştırmalı Çalışma

- T2: Gögüs Hastalıkları Servisinde Yatan Koah Hastalarında Müzik Terapisinin Anksiyete ve Bazı Klinik Bulgulara Etkisi

- T3: Dinî İçerikli Müzik Terapinin Üniversite Öğrencilerinde Duygu Durumu, Kaygı ve Algılanan Stres Düzeyi Üzerindeki Etkisi

- T4: Hemodiyaliz Tedavisi Alan Hastalarda Müzik Terapinin Ağrı, Yorgunluk, Anksiyete ve Kaşıntı Semptomları Üzerine Etkisi

- T5: Kanser Hastalarına Dinletilen Müziğin, Kemoterapi Yan Etkilerine ve Durumluk- Sürekli Kaygı Düzeylerine Etkisinin İncelenmesi

- T6: Klasik Türk Müziğinin Hipertansiyon Hastalarının Kan Basınçlarına ve Anksiyete Düzeylerine Etkisi

- T7: Kemoterapi Uygulanan Hastalarda Müzik Terapinin Kemoterapi Semptomları ve Konfor Düzeyine Etkisi

- T8: Koroner Anjiyografi Uygulanacak Hastalarda Müzik Terapisinin Anksiyete Düzeyine Etkisi

- T9: Koroner Arter Bypass Greft Ameliyatı Uygulanan Hastalarda Müzik Terapinin Temel Yaşam Bulguları, Ağrı, Anksiyete ve Hastanede Kalış Sürelerine Etkisi

- T10: Mekanik Ventilasyonlu Hastanın Aspirasyon İşleminde Uygulanan Müzik Terapinin Ağrı ve Fizyolojik Parametrelere Etkisi

- T11: Mekanik Ventilatör Desteğinde Olan Hastalarda Müzik Terapinin Anksiyetenin Fizyolojik Belirtilerine Etkisi

- T12: Müzik Terapinin Cerrahi Uygulanan 6-12 Yaş Arası Çocuklarda Anksiyete, Korku ve Ağrı Yönetimine Etkisi

- T13: Müzik Terapinin Cerrahi Yoğun Bakım Hastalarının Yaşam Bulgularına Etkisi

- T14: Müzik Terapinin Huzurevinde Yaşayan Yaşlıların Yalnızlık Hissi Üzerine Etkisi

- T15: Müzik Terapinin Kolonoskopi Öncesi Hastaların Fiziksel ve Ruhsal Parametreleri Üzerine Etkisinin İncelenmesi

- T16: Müzik Terapisinin Hemodiyaliz Hastalarının Algıladıkları Stresörler ve Anksiyete Düzeyleri Üzerine Etkisi 
- T17: Müzik Terapisinin Yaşı Kanser Hastalarının Anksiyete ve Uyku Kalitesi Üzerine Etkisi

- T18: Müzikle Terapinin Sınav Kaygısı, Öfke ve Psikolojik Belirtiler Üzerindeki Etkisi

- T19: Serebral Palsili Çocuklarda Nörolojik Müzik Terapi Eğitiminin Yaşam Kalitesi, Katılım ve Günlük Yaşam Aktiviteleri Üzerine Etkisi

- T20: Stres ve Anksiyete İçin Alternatif ve Tamamlayıcı Bir Model Olarak Müzik Terapi

- T21: Şizofreni Hastalarında Müzik Terapinin Depresyon, İşlevsellik, Genel Psikopatoloji Klinik Parametreleri Üzerine Etkileri

- T22: Şizofrenik Hastalarda Müzik Terapinin Ruhsal Durum Üzerine Etkileri

Tablo 2. Uygulamalı müzik terapi konulu makalelerin, içeriklerinde yer alan müziklerin özellikleri ve uygulandı̆̆ı terapi yöntemlerine göre dağılımları

\begin{tabular}{|c|c|c|c|c|c|c|c|c|}
\hline \multirow[t]{3}{*}{$\begin{array}{l}\text { Makale } \\
\text { Kodu }\end{array}$} & \multicolumn{3}{|c|}{$\begin{array}{l}\text { Kullanılan Müziklerin } \\
\text { Özellikleri }\end{array}$} & \multicolumn{5}{|c|}{ Terapi Uygulamalarının İçeriği } \\
\hline & \multirow[t]{2}{*}{ Tür } & \multicolumn{2}{|c|}{ Dinletim şekli } & \multirow[t]{2}{*}{ Yer } & \multirow[t]{2}{*}{ Süreç } & \multirow{2}{*}{$\begin{array}{l}\text { Haftalık } \\
\text { Terapi } \\
\text { Süresi }\end{array}$} & \multirow{2}{*}{$\begin{array}{l}\begin{array}{l}\text { Den } \\
\text { ek }\end{array} \\
\text { Sayı } \\
\text { s1 } \\
\end{array}$} & \multirow{2}{*}{$\begin{array}{l}\text { Eser } \\
\text { Adedi }\end{array}$} \\
\hline & & Canlı & Kayıt & & & & & \\
\hline M1 & $\begin{array}{l}\text { Uşak } \\
\text { Makamı }\end{array}$ & - & $\mathrm{Cd}$ & $\begin{array}{l}\text { Huzur } \\
\text { evi }\end{array}$ & $\begin{array}{l}4 \\
\text { Hafta }\end{array}$ & $60 \mathrm{dk}$. & 31 & - \\
\hline M2 & $\begin{array}{l}\text { Klasik } \\
\text { Batı Müziği } \\
\text { (Barok D.) } \\
\text { Vivaldi } \\
\end{array}$ & - & Mp3 & Klinik & $\begin{array}{l}1 \\
\text { defa }\end{array}$ & $60 \mathrm{dk}$. & 11 & 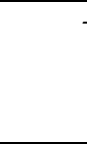 \\
\hline M3 & $\begin{array}{l}\text { Hüseyni } \\
\text { Makamı }\end{array}$ & - & Mp3 & Klinik & $\begin{array}{l}1 \\
\text { defa }\end{array}$ & $30 \mathrm{dk}$. & 60 & 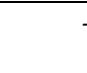 \\
\hline M4 & $\begin{array}{l}\text { Klasik } \\
\text { Türk } \\
\text { Müziği- } \\
\text { Acemhaşir } \\
\text { an Makamı }\end{array}$ & - & Mp3 & $\begin{array}{l}\text { Erciyes } \\
\text { Ün- } \\
\text { iversi- } \\
\text { tesi }\end{array}$ & $\begin{array}{l}3 \\
\text { ay }\end{array}$ & - & 70 & - \\
\hline M5 & $\begin{array}{l}\text { Kendi } \\
\text { Tercih } \\
\text { Ettikleri } \\
\text { Müzik }\end{array}$ & - & Mp3 & - & & $120 \mathrm{dk}$. & 13 & - \\
\hline M6 & $\begin{array}{l}\text { Ritimli } \\
\text { Müzikler }\end{array}$ & $\begin{array}{l}\text { Piyano, } \\
\text { saz, } \\
\text { kemençe }\end{array}$ & $\mathrm{Cd}$ & Klinik & $\begin{array}{l}24 \\
\text { Ay }\end{array}$ & & 188 & 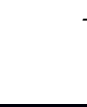 \\
\hline
\end{tabular}


Tablo 2 elde edilen verilere göre, yazılan makalelerde müzik terpi uygulamalarında çoğunlukla belirli makamlar dinletilmiştir. Kulaklık yöntemiyle dinletilen müzikler ortalama 60 dakika sürmüştür. Çalışmalarda en az 11, en fazla 188 kişi kullanılmıştır. Aktif müzik terapi de kullanılan makale çalışmalarında; piyano, saz, kemençe çalgıları kullanılmıştır.

- M1: Huzurevinde Kalan Yaşlılarda Pasif Müzikoterapinin Uyku Kalitesine Etkisi

- M2: Mekanik Ventilasyon Desteğinde Olan Hastalarda Müzik Terapinin Sedasyon Düzeyi ve Yaşamsal Belirtiler Üzerine Etkisi: Bir Pilot Çalışma

- M3: Müzikterapinin Kolesistektomi Olan Hastaların Ağrıları Üzerine Etkisi

- M4: Perkütan Koroner Girişim Uygulanan Hastalarda Müzik Terapinin Anksiyete Düzeyi ve Yaşam Bulgularına Etkisi; Randomize Kontrollü Çalışma

- M5: Tinnitusu Olan Bireylerde Müzik Terapisinin Yaşam Kalitesi Üzerine Etkisi

- M6: Türkiye'de Nörolojik Rehabilitasyon Kapsamında Bir Müzik Terapi Projesinin Geliştirilmesi,

Müziğin terapide etkisinin ölçülmek istenildiği uygulamalı araştırmalar tasarlarken, Uygulamalı Müzik Terapi ortamlarında kullanılmak istenilen müziklerin seçiminde dikkat alınması gereken hususlar nelerdir?

\section{Uzmanların 2. Soruya verdikleri yanıtlar ile ilgili Açık Görüşleri,}

.... Müzik terapide müzik seçimi, kişiye özel kültürel değerleri ön planda tutmaya ve müziğin evrensel gücünü kullanmaya çalışarak yapılır. Terapist, terapide kullanılacak müziği seçerken, katılımcının özgeçmişini ve yaşanmışlıklarını, müziğin katılımonnı aklına getirdiklerini ve çă̆rıştırdıklarını, katılımoının müzikal aşinalıkların ve alışkanlıklarını, müzikal deneyimlerini, duygu durumunu ve tedavi bağlamın göz önünde bulundurur (U1). 
.... Terapi hizmeti alacak olan kişinin müzik geçmişi (geçirdiği farkh gelişim evreleri süresince ve yetiştiği çevrede temas kurduğu müzik türleri, ait hissettiği/benimsediği kültürel altyapıy yansıtan müzik türleri, kendi yaşam öyküsüne dahil ettiğgi müzik türleri), müzik deneyimi, müzik tercihleri (sevdiği müzik türleri ve sanatçılar) ve müzik gereksinimleri (terapi sürecinde gündeme getirmek/üzerinde çalışmak/dinlemek/çalmak istediği türler ve parçalar). Bonny'nin Rehberli Imgelem ve Müzik Yöntemi gibi bazı modellerde terapist, önceden belirlenmiş müzik programları kullanabilir, bazı durumlarda ise doğrudan kendi seçtiği müzikleri çalabilir/seslendirebilir. Ancak söz konusu durumlarda da yine hizmet alacak kişinin gereksinimlerinin, seçimlerle ilgili tepkilerinin ve geribildirimlerinin dikkate alınması, müzik seçimlerinin terapinin hedefine uygun biçimde belirlenmesi gerekmektedir. Terapist, dinletmeyi velveya seslendirmeyi planladığ müzik velveya sesleri, terapi oturumundan önce kendi üzerinde de deneyimlemelidir (U2).

.... Aşağıdaki tanımdan görüleceğgi üzere müzik terapinin, müzik terapi eăitimi almış bir müzik terapist tarafından uygulanabileceği unutulmamalıdır.

Müzik terapi,

- müzik eğitimi almış profesyonel bir terapist tarafindan,

- müzikal terapötik müdahalelerin,

- klinik çerçevede ve kanıta dayaklı şekilde,

- bir terapötik ilişki içerisinde,

- $\quad$ kişiye özel belirlenen hedeflere yönelik kullanılmasıdır (Amerika Müzik Terapi Derneği).

Kesinlikle kişiye özel müzikler seçilmelidir. (Kişinin hayatında hangi müzik varsa ). Müzik seçimine bazen hastaldanışan, bazen müzik terapisti, bazen de hastaldanışan ve müzik terapisti birlikte karar vermektedir (U3).

... Hasta veya danışanın ihtiyacına göre müzikleri belirlemek, ondan müzikal bir yeterlilik beklememek ve yönlendirme yapmamak. Kendisine alan açıp rahat bir şekilde ifade etmesi imkânın verip gözlemlemek. (U4).

.... Müzik terapi uygulamalarında "müzik seçimi" şeklinde bir konu yoktur. Terapi süreci müzik üzerinden kurulan terapötik ilişki ile sağlanır. Yani, terapist ve danışan birlikte müzik üretirken tedaviye yönelik hedeflere ulaşırlar. Reseptif Müzik Terapi yöntemlerinden BM-GIM'de klasik batı müziği repertuvarından seçilmiş eserler kullanılır. Diğer yöntemlerde ise hastanın müzik altyapısı, müzik beğenisi, tercihleri etkili olur (U5). 
Müziğin terapide etkisinin ölçülmek istenildiği uygulamalı araştırmalar tasarlarken, Müzikle Terapide aktif veya pasif uygulamalardan hangisi tercihi edilmelidir? nedeni ile belirtiniz?

\section{Uzmanların 3. Soruya verdikleri yanıtlar ile ilgili Açık Görüşleri,}

.... Müzik terapide katılımonmn ihtiyaçlarma göre hem aktif, hem de reseptif (pasif) uygulamalar tercih edilebilir. Genel müzik terapi yelpazesi düşünüldüğünde aktif uygulamalara daha çok başvurulur. Bilinci kapal, komadaki bir hastanın kendini ifade ve bedenini kontrol imkan kısıtlı olduğu için reseptif uygulamalar tercih edilebilirken kısmen de olsa sözel veya müzikal iletişim kurabilen, kısmen de olsa bedenini kontrol edebilen katılımollar için aktif uygulamalar tercih edilebilir. (U1).

.... Öncelikle, bu anketi dolduran kişiye göre, "pasif" bir müzik terapi türü yoktur. Onun yerine tercih edilebilecek "reseptif" teriminde bile, müzik terapiye gelen kişinin "alıcı" konumunda olduğunu, müziksel deneyime en azından bedensel, fizyolojik, nörobiyolojik vb. düzlemde aktif olarak katıldığın göz önünde bulundurmak gerekir. Aktif ve reseptif yöntemler arasındaki seçim, terapinin hedef (ler)i doğrultusunda belirlenir. Gelişimsel Koordinasyon Bozukluğu bulunan bir bireyle kaba motor becerilerinin denetimi üzerine çalışırken ya da Travma Sonrası Stres Bozukluğu yaşayan bir bireyle duygu dışavurumu üzerine çalışırken, doğrudan bireyin perküsyon kullanabileceği aktif yöntemler uygulanabilir. Ancak içgörü, sembolizasyon, otobiyografik düzenleme vs. odaklı bir seansta, ayn bireylerle terapist eşliğinde müzik dinleme ağırlkkl, yani reseptif çalışmalar yürütülebilir (U2).

.... Müzik terapinin hedefine göre, yaklaşım, metot, teknik seçimi değişmektedir. Herhangi bir hastalık için spesifik bir metot bulunmamaktadır. (U3).

.... Çalıştığın hasta ve danışan popülasyonun sağllk durumuna göre olup terapistin neyi hedeflediğine bağlıdır. Örneğin: Bedensel sağlık sorunları olan felçli hastalarda, yoğun bakım hastalarında, bebeklerde Rezeptif müzik terapi uygulanır. Çünkü aktif uygulamada terapiste eşlik edemezler. (U4).

.... Hastanın ya da danışanın ihtiyacına göre belirlenir. Örneğin, bir hasta çeşitli şikayetleri ile doktora gittiği zaman konulan teşhise göre ve ulaşılmak istenen sağlık hedefine göre tedavi belirlenir. Yani hastanın cerrahi tedavi mi alacağı, yoksa ilaç tedavisi mi alacă̆g, hastanın tanısı konulmadan karar verilen bir durum değildir. (U5). 


\section{Müzikle Terapide müziğin kullanımını kapsayan uygulama aşaması ge- nel olarak,}

\section{Nasıl Bir Sıra İle Gerçekleşebilir?}

\section{a- Uzmanların 4. Sorunun a şıkkına verdikleri yanıtlar ile ilgili Açık Görüşleri,}

.... Terapi süreci ve seansinın durumuna göre seans ilerleyişine ve müzik kullanılan bölümlerin sırasına terapist karar verir. Genelde müzikal uygulama/lar seansin ortalarında yer alır ama bu değişkenlik gösterebilir. Örneğin terapist bir selamlaşma ve sohbet bölümünden sonra müzik kullanmayı planlayabilir ancak katılımcının odaya girdiğ $i$ anda enstrumanlara yönelip çalmaya başlaması sebebiyle sohbet bölümünü atlayıp müziğe geçmeye karar verilebilir. Veya başka bir örnekte, terapist o seansta sözel iletişimle daha iyi yol kat edilebildiğini gözlemlemişse, planlandığı halde müzik kullanmamayı seçebilir (U1).

.... Durum ve uygulama olasılıklarındaki çeşitliliğine bakıldığında, tek ve değişmez bir siralamadan söz etmek mümkün değildir. Bununla birlikte, yalnızca genel bir işleyiş örneği olarak aşağıdaki gibi bir sıralama izlenebilir:

a- Seans başında tanışma, ısınma, bir önceki seanstan bu yana bireyin yaşadıkların aktarması vb. sırasında ortaya çıkan temalar VE/VEYA bireyin o gün özellikle üzerinde çalışmak istediği tema VE/VEYA genel tedavi programinın ilerleyişinde gelinen noktaya göre kullanılacak müziklerin belirlenmesi

b- Uygulama

c- Uygulamadan hemen sonra, kullanılan müzikle ilgili olarak bireyden geribildirim alınması (burada geribildirim terimi, geniş anlamda değerlendirilmeli; yalnızca sözel geribildirimle sinırlı tutulmamalıdır).

d- Geribildirim strasında ortaya çıkabilecek yeni tema, gereksinim vb. doğrultusunda, olast yeni uygulama

e- $V b$. (U2).

.... Müzik terapi, zamanla gerçekleşen bir süreçtir. Terapi olarak görülebilmesi için, bu süreç bir terapistin müdahalesini gerektirir. Amaçlar eğitimsel, rekreasyonel (eğlenme-dinlenme odakli), rehabilitatifliyileştirici, koruyucu veya psikoterapi şeklinde olabilir ve danışanm fiziksel, duygusal, düşünsel, sosyal veya ruhsal gereksinimlerine odaklanır. Tedavi yöntemleri dinleme, doğaçlama, icra, 
besteleme, hareket etme veya konuşma üzerinde yoğunlaşabilir ve sanat, dans, tiyatro ve şïr alanlarından ek deneyimler içerebilir (Bakını "Müzik Terapiyi Tanımlamak" kitabı).

Müzik terapi klinik çerçevede ve kanıta dayalı bir süreçtir. Süreç:

- Danışanın/hastanın değerlendirilmesi

- Terapi planlamasi

- Terapi uygulamasi

- Terapi değerlendirmesi

- Belgelendirme/raporlaştırma

- Sonlandirma/taburcu süreçlerini içerir. (U3).

.... Müzik terapide müziğin uygulanması warm-up (ısınma) aşamasında başlar. Akabinde sözlü oturum oluşur (hasta/danışanın o gün yanlarında getirdikleri konu) ve bu konu ile müzikal uygulama başlar. O gün ki seansta aktif veya pasif müzik uygulaması hem danışanın ihtiyacına göre hem de terapistin o seanstaki hedefine göre belirlenir. (U4).

.... Bir müzik terapi seansının yapılandırılması, uygulanacak yaklaşıma göre değişebilir. Davranışsal Müzik Terapi'deki seans ile Kreatif Müzik Terapi'deki seans yapısı aynı olmayabilir. Bireysel terapilerde danışan, müzik terapi odasına alınırken (özellikle çocuk yaşta ise) bir karşılama müziği ve ostinato ile ısınma yapılabilir, daha sonra bir müzikal diyalog gerçekleştirilebilir ve sonra bunun getirdiği düşünceler paylaşılır ya da çizim ya da kilden heykel yapımı gibi kreatifbir aktivite ile sonlandirllabilir. Müziğin kullanıldı̆̆g anlarda terapist müzik yapabilir, danışan müzik yapabilir veya her ikisi birlikte müzik yapabilir. Bunu o andaki koşullar ve tercihler belirler. (U5).

\section{Bu Süreçte Nelere Dikkat Edilmelidir?}

\section{a. Uzmanların 4. Sorunun B Şıkkına Verdikleri Yanıtlar İle İlgili Açık Görüşleri}

.... Bu süreçte dikkat edilmesi gereken en önemli şey, terapistin kabul edici olması, zorlayıcı olmamasıdır. Müzikal uygulamayı - gerekli görüyorsa - önerebilir, uygulamaya teşvik edebilir, ancak zorlayıcı olamaz. Bazen katılımoının reddine gösterilen kabul, en önemli terapötik (sağaltıcı) unsur olur. (U1). 
.... Uygulamanın yapıldığı bireyden gelebilecek her tür tepkiyi gözlemleyip dikkate almak (itiraz, saldırganlık, çalışmaya son verme isteği, "tepkisizlik", uykuya dalma, bilinç düzeyinde meydana gelebilecek değişiklikler dahil. Grup arkadaşlarryla "seans kaynatma", sürekli tuvalete gitmek için izin isteme, telefonuyla oynama vb. gibi tepkilere de semptomatik değer taşıyan veriler/terapiste verilmek istenen mesajlar gözüyle yaklaşılmalıdır). Herhangi bir cihaz/düzenek aracıllğıyla ölçüm yapılmakta ise (örn. biofeedback/biyolojik geribildirim uygulamalarl), bunun takibini sağlayabilecek ikinci bir terapistin de seansta hazır bulunmasında yarar olabilir. (U2).

.... Müzik terapide doğaçlama, besteleme, yaratma, yeniden yaratma ve pasif metotlar ve bu metotları içerisinde onlarca farkl teknik bulunmaktadır. Müzik terapi eğitimi almamış kişiler tarafından Hastaya/danışana müzik dinletmek müzik terapi değildir. Sağlıkla ilgili hedefler için, ancak müzik terapi niteliğ $i$ taşımayan yollarla müzik kullanılıyor ise, kullanılan bu uygulamalar müzik tıbbr (music medicine) olarak ya da sadece müzik dinle(t)mek olarak tanımlanabilir. Diğer taraftan ülkemizde de yapılan; hasta başında yapılan müzik dinletileri, hastalardan ya da sağlık personelinden oluşturulan korolar sağlıkta müzik uygulamaları olarak değerlendirilmelidir (U3).

.... Ĕger hasta tarafindan müzik uygulanıyorsa, hastanın eline aldığı her enstrüman, çaldı̆̆ $\mathrm{m}$ melodi, ritim, ses vb. terapist tarafindan sakince sonuna kadar dinlenmek zorundadır. Hiçbir şekilde bölemez. Diğer bir metot olan Reseptif uygulamada terapist tarafindan hastaya dinletilen müzik hasta tarafindan yarıda kesiliyorsa (kriz oluşumuna sebep olabilir) terapist müziği yarıda kesip hastanın ihtiyacın karşılamalıdır. (U4).

... Danışanın güvenini kazanmak ve güven üzerine kurulan dayanışmayı (terapist-danışan ilişkisini) tedavi hedefleri doğrultusunda kullanmak (U5).

\section{Sonuç ve Değerlendirme}

Araştırmanın 1. alt amacına yönelik elde edilen bulgulara göre, müzik terapi uygulamaları içeren toplam 22 akademik tezin 5'inde aktif müzik terapiden yararlanıldığı ve bu terapilerde ney, davul, kaval gibi enstrümanlar kullanıldığı, 17 çalışmada ise pasif müzik terapi kullanıldığı ve bu terapilerde Cd kaydı dinletildiği görülmektedir. Gerçekleştirilen tezlerde yürütülen müzik terapi uygulamalarında genellikle pasif müzik terapinin daha ağırlıkta olduğu görülmektedir. Bunun temel nedenlerinden birisi 
olarak bazı araştırmacıların müzik terapi alanında yeterli seviyede uzmanlığa sahip olmadıkları ve dolayısıyla çalışmalarında pasif müzik terapi tercih ettikleri söylenebilir. Bu uygulamalarda ağırlıklı olarak Türk Müziği makamları dinletilmiştir. Uygulamalarda haftalık terapi süresine bakıldığında dinletilen müziklerin 10 ile 120 dakika arasında değiştiği görülmektedir. Uygulamanın tüm sürecine bakıldığında sürecinin en fazla 16 hafta olduğu en az ise bir defalık terapi çalışması olduğu belirlenmiştir. Tezlerin uygulama süreçlerinin içerik ve kapsamına göre değişik gösterdiği görülmekte olup bu doğrultuda bakıldığında çalışmaların uygulama süreçlerinde farklılıklar olabileceği düşünülmektedir.

Tablo 2 deki gerçekleştirilen akademik makalelere bakıldığında, genellikle cd kaydı ve kulaklık kullanılarak müziklerin dinletildiği ve müzik türü olarak çoğunluğu Türk müziği makamlarından oluştuğu görülmektedir. Bu çalışmalarda haftalık müzik dinletme sürelerinin en az 10, en fazla 120 dakika sürdüğü tespit edilmiştir. Tüm uygulama süreci en fazla 24 ay en az ise bir uygulama olduğu belirlenmiştir. Tez çalışmalarında olduğu gibi Pasif müzik terapinin ağırlıkta olduğu görülmektedir.

2. Alt amaca göre elde edilen bulgulara göre, terapistlerin uygulamada kullanılacak müziğin seçimi konusunda terapinin içeriğine ve danışanın (hastalar) durumuna göre değişiklik gösterdiği anlaşılmaktadır. Danışanların kişisel geçmişinin ve isteklerinin göz önünde bulundurulması gerektiği ortaya koyulmuştur. Uzmanlar, terapide kullanılacak müziğin seçimi konusunun bazı durumlarda danışana bırakıldığı, bazen terapistin tercih ettiği ya da beraber karar verildiği ve bazen de müziğin önceden seçilmediği terapi esnasında yaratım olduğu yönünde görüş ortaya koymuşlardır. Müzik terapinin, müzik terapi eğitimi almış uzmanlar tarafından yapılmış olması gerektiği vurgulanmıştır.

3. Alt amaca göre elde edilen bulgulara göre, Müzik terapide, terapinin içeriği ve danışanın durumuna göre aktif veya reseptif (pasif) uygulamalar tercih edildiği görülmektedir. Uzmanlar, aktif veya pasif müzik terapinin seçiminin danışanın ve terapistin terapi sonucundaki hedeflediği durumlarla belirlenmesi gerektiğini vurgulamışlardır. Danışanın bireysel ve kültürel özellikleri aktif terapide kullanılacak çalgının seçiminde önemli olduğu belirlenmiştir. Ağır vakalarda aktif müzik terapi uygulanamayacağı, belirli bir hastalık için kesin bir yöntem olmadığı uzmanlar tarafından ortaya koyulmuştur. 
4. Alt amacın a şıkkından elde edilen bulgulara göre, uzmanlar, müzik terapide müziğin uygulama aşamasının tek bir sıralama şeklinde olmadığını, danışanın özellik ve ihtiyaçlarına uygun olan uygulama ya da yaklaşımların olabileceğini, bu sürecin seyrine terapistin karar verdiğini belirtmişlerdir. Müzik terapinin süreç ve uygulamada bir çeşitlilik söz konusu olduğu anlaşılmıştır.

4. Alt amacın b şıkkından elde edilen bulgulara göre, uygulama aşamasında nelere dikkat edilmesi gerektiği konusunda uzmanlar, terapistin danışana karşı kabul edici olması, zorlayıcı olmaması gerektiğini, danışandan gelebilecek her türlü tepkinin dikkate alınmasını, bazı ölçümlerdeki verilerinin toplanılmasında ikinci bir terapiste ihtiyacın doğabileceğini, müzik terapide birçok metot ve teknik yer aldığ 1 için bu uygulamaların müzik terapi uzmanları tarafından gerçekleştirilmesi gerektiğini, terapi esnasında danışanın yaptığı müziğin kesilmemesi ve müzik dinletirken danışanın müdahale ve ihtiyaçlarına dikkat edilmesi gerektiğini ve danışan ve terapist arasında bir güven bağı oluşmasına dikkat edilmesinin gerekliliğini vurgulamışlardır. 


\title{
EXTENDED ABSTRACT
}

\section{The Music Used In Music Therapy Practice in Turkey}

\author{
* \\ Begüm Yilmaz - Ümit Kubilay Can \\ Kocaeli University
}

Music is regarded as the oldest field of art for societies. Many societies throughout history have incorporated music in art and medicine and conducted research. Some primitive societies regarded music as a sacred way of communication with gods, and certain instruments were described as the voice of god. Music through deification gained importance in human life and came to use in all areas of life. The use of music in music therapy started when primitive tribes employed it to cure diseases they called evil spirits according to their beliefs, and, later on, music was introduced to the clinical setting as a field of science. In early applications of music therapy, music was played to patients with a certain disease, and music therapy moved on to become a subdomain of psychology. The music played is a main characteristic of music therapy applications. Clinical studies show that there is no defined method on the selection and use of music, and therapists choose the music based on their practices.

Music therapy is deep-rooted in Turkish history, and it is known that music was used in the treatment of patients in hospitals. It is known that specific modes were used for specific diseases, and Al-Farabi in his book refers to the healing properties of modes. Music Therapy is an emerging field of science in Turkey. The number of agencies, experts and researchers who work on music therapy is relatively low compared to international figures, but it is seen that interest in music therapy is gradually growing in Turkey. Organizations like the Turkish Music Therapy Application and Research Group (TÜTEM), the Group for the Research and Promotion of Turkish Music (TÜMATA), and the Turkish Music Therapy Association (MÜZTED) study music therapy and organize seminars and workshops to promote music therapy. 
This paper aims at analyzing the music used in music therapy. Accordingly, the problem of this paper has been designated as the contents of musical practices included in academic studies on music therapy and how these practices are implemented, and opinions of music therapy specialists on the matter. The following questions are asked in line with the goal of the paper:

1. What are the contents of applications included in music therapy practices in Turkey and characteristics of the music used in these practices?

2. While designing the applied studies to measure the effect of music in therapy;

3. What are the points to take into consideration in the selection of music to be used in the Applied Music Therapy setting?

4. Which of the active or passive applications should be preferred in music therapy?

5. Generally, concerning the application stage that covers the use of music in music therapy;

a) In what order should the application be carried out?

b) What are the points to take into consideration during this stage?

It is believed that the results of the study will illuminate the current situation through the identification of musical contents used in music therapy studies in Turkey and taking expert opinion. Moreover, it is thought that the results will provide guidance for researchers and therapist in future studies.

Descriptive pattern was used as the mixed research method of this paper. According to the mixed method, quantitative data was used to solve some of the questions and qualitative data was used in other questions pursued in this paper. Population of the study consists of all publications that contain Applied Music therapy studies published in Turkey to identify quantitative data, and sample group of the paper consists of all articles and theses. The articles and theses used to collect the quantitative data of the paper were identified using keywords related to music therapy. An expert opinion form was prepared by the researcher and presented to five experts in the field to describe the current situation concerning the qualitative data of the paper. 
According to the findings, 5 of a total of 22 academic theses on music therapy applications employed active music therapy, and instruments like the ney, the drum and the kaval were used in these studies, and 17 thesis used passive music therapy, using CD recordings. Passive music therapy appears to predominate the music therapy practices carried out as part of the academic theses. These studies mostly used Turkish music modes in their applications.

Contents of the academic articles prepared in Turkey show that music is mostly played using a CD recording and headphones, and Turkish music modes are generally the preferred type of music. Similar to academic thesis, articles mainly consist of passive music therapy as well.

Apparently, therapists choose the music in their practices based on therapeutic context and the status of the client (patient). It has been demonstrated that the personal history and wishes of clients should be taken into consideration. Experts expressed their opinions that the client may be allowed to choose the music to be used in therapy, the therapist may choose the music or it may be a joint decision, and sometimes the music is not preselected and is generated during therapy. It was noted that music therapy should be performed by trained experts.

In music therapy, it is observed that a choice is made between active or receptive (passive) applications based on the therapy and client status. Experts stressed that the choice of active and passive music therapy should be made according to therapy objectives for the client and the therapist. Individual and cultural characteristics of the client appear to play a role in the selection of musical instrument to be used in active therapy. Experts revealed that music therapy cannot be used for more severe cases and there are no precise methods for specific diseases.

Experts also expressed that the application stage of music therapy is not a linear process, and the application or approach could be adapted to the characteristics and needs of the client and therapist determines the course of the process. It appears that the application of music therapy is a diversified process.

On the points to take into consideration in the application process, experts stressed that the therapist should be receptive towards the client, avoid forcing the client, take all reactions of the client into consideration, 
and a second therapist may be required to collect data in certain measurements, music therapy experts must perform the numerous methods and techniques used in music therapy, music performed by the client during therapy should not be interrupted, interventions and requirements of the client should be paid attention while playing music, and a relationship of trust should be established between the client and the therapist.

\section{Kaynakça / References}

Ak, Ş.A. (1997). Avrupa ve Türk İslam medeniyetinde müzikle tedavi, Konya: Öz Eğitim Basım Yayım.

Arslan, S. ve Özer, N. (2007). Dokunma, müzik terapi ve aromaterapinin yoğun bakım hastalarının fizyolojik durumlarına etkisi, Yayınlanmamış Doktora Tezi, Atatürk Üniversitesi Sağllk Bilimleri Enstitüsü, Erzurum.

Bekiroğlu, T. (2011), Klasik Türk Müziğinin hipertansiyon hastalarının kan basınçlarına ve anksiyete düzeylerine etkisi, Yayınlanmış Yüksek Lisans Tezi Gaziantep Üniversitesi Sağlık Bilimleri Enstitüsü, Gaziantep.

Bruscia, E. K. (2016). Müzik terapiyi tanımlamak. (Çec. B. Uçaner Çifdalöz vd.) İstanbul: Nobel Yaşam.

Büyüköztürk, Ş. (2005). Anket geliştirme. Türk Eğitim Bilimleri Dergisi, 3(2), 133-151.

Creswell, J. W. (2013). Araştırma deseni, nitel, nicel ve karma yöntem yaklaşımları. (E. Bukova Güzel, İ. Erdoğan, Y. Dede, G. Haciömeroğlu, H. Ercan, F. I. Bilican, M. Bütün, M. Bursal, S. Şahin Mandacı ve S. B. Demir, Çev.). Ankara: Eğiten Kitap.

Creswell, J. W. (2017). Karma yöntem araştırmalarına giriş (M.Sözbilir Çev.). Ankara: Pegem Akademi.

Ersanl, C. (2007). İndüksiyon uygulanan primipar gebelere trvayda verilen eğitim ile dinletilen müziğin doğum sürecine etkisi, Yayınlanmamış Yüksek Lisans Tezi, Marmara Üniversitesi, İstanbul.

Gençel, Ö., (2006). Müzikle tedavi, Kastamonu Eğitim Dergisi, 14(2), 697- 706.

Greene, J. C., Caracelli, V. J. ve Graham, W. F. (1989). Toward a conceptual framework for mixed-method evaluation designs. Educational evaluation and policy analysis, 11(3), 255-274. 
Horuz, D. (2014). Göğ̈̈s hastalikları servisinde yatan koah hastalarında müzik terapisinin anksiyete ve bazı klinik bulgulara etkisi, Yayınlanmamış Yüksek Lisans Tezi, Bülent Ecevit Üniversitesi, Sağlık Bilimleri Enstitüsü, Zonguldak.

Karataş, Z. V. (2015). Bireyi tanımada test dışı teknikler. Nobel Akademik

Öztürk, L., Erseven, H. ve Atik, F. M., (2017). Makamdan şifaya. İstanbul: İş Bankası Yayınları.

Sönmez, D. (2008). Antik Dönemde Anadolu'da müzik ve müzik aletleri. Yayınlanmamış Yüksek Lisans Tezi, Selçuklu Üniversitesi Sosyal Bilimler Enstitüsü, Konya.

Stanczyk, M. M., (2011). Music therapy in supportive cancer care. Reports of Practical Oncology and Radiotherapy. 1(6), 170-172.

Uçaner, B. ve Tufan, E. (2008), History and current applications of Turkish music therapy. XII Congreso Mundial de Musicoterapia 2008, Libreri'a Akadia Editorial, 22-26 July, Argentina.

Uçaner, B. ve Öztürk, B., (2009). Türkiye'de ve dünyada müzikle tedavi uygulamaları. Çanakkale 18 Mart Üniversitesi, I. Eğitim veAraştırma Kongresi,1-3 Mayıs, Çanakkale.

Uygun, M. N. (1999). Safiyüddin Abdülmü'min Urmevî ve Kitâbü'l Edvârı. İstanbul: Kubbealtı Neşriyatı.

Wheeler, B. L. (Ed.). (2015). In Music therapy handbook. New York: Guilford Yayınları. 196-205.

Wigram, T. ve Grocke, D. (2007). Receptive methods in music therapy. UK ve USA:Jessica Kingsley Publishers.

Yıldırım, G. ve Gürkan, A. (2007). Müziğin kemoterapi yan etkilerine ve kaygı düzeyine etkisi. Anadolu Psikiyatri Dergisi, 8(1), 37-45.

\section{Kaynakça Bilgisi / Citation Information}

Can, Ü. K. ve Yılmaz, B. (2019). Türkiye' de müzik terapi uygulamalarında kullanılan müzikler OPUS-Uluslararası Toplum Araştırmaları Dergisi, 13(19), 592-620. DOI: 10.26466/opus.584795 